\title{
Non-pharmacological management of neonatal pain: Research and clinical practice in the Neonatal Intensive Care Unit
}

\author{
Manejo não farmacológico da dor neonatal: pesquisa e prática clínica \\ na Unidade de Terapia Intensiva Neonatal
}

Maria Beatriz Martins LINHARES'

Cláudia Maria GASPARDO'

\begin{abstract}
According to the World Health Organization and the International Association for the Study of Pain, pain is a relevant worldwide problem in the healthcare field. The present study aimed to describe the definition of pediatric pain and the main characteristics, and to examine the findings regarding the impact of pain on the development of the child. The best clinical practices in Neonatal Intensive Care Units should include developmental care and specifically implement pain management, aiming to protect the health and development of the infants. The efficacious non-pharmacological management of neonatal pain includes breastfeeding, skin-to-skin, non-nutritive sucking, facilitated-tucking and swaddling. Sweet solutions also have pain relief effects. Psychologists could actively participate in the implementation of non-pharmacological interventions and in the whole process to sensitize and train the professional teams, to alert parents to protection against pain and to support policymakers in the implementation of pain guidelines in the hospital.
\end{abstract}

Keywords: Infants; Pain; Pain management.

\section{Resumo}

De acordo com a Organização Mundial de Saúde e a Associação Internacional para o Estudo da Dor, a dor é um problema mundial relevante na área da Saúde. O presente estudo teve por objetivo descrever a definição da dor pediátrica e principais características, assim como examinar achados sobre impactos da dor no desenvo/vimento da criança. As melhores práticas clínicas devem incluir o cuidado ao desenvolvimento nas Unidades de Terapia Intensiva Neonatal e, especificamente, a implementação do manejo da dor, visando proteger o desenvolvimento e saúde dos bebês. O manejo não-farmacológico da dor neonatal inclui amamentação, leite humano, sucção não-nutritiva, toque facilitador e enrolamento. As soluções adocicadas, como glicose e sacarose, também têm efeitos de alívio de dor. Psicólogos podem participar ativamente das intervenções não-farmacológicas e todo processo de sensibilizar e treinar equipes de profissionais, alertar familiares para proteção contra a dor e dar suporte aos dirigentes na implementação dos protocolos de dor no hospital.

Palavras-chave: Bebês; Dor; Manejo da dor.

${ }^{1}$ Universidade de São Paulo, Faculdade de Medicina de Ribeirão Preto, Departamento de Neurociências e Ciências do Comportamento. Av. Tenente Catão Roxo, 2650, Prédio da Saúde Mental (salas 52/53), Campus Universitário Monte Alegre, 14048-900, Ribeirão Preto, SP, Brasil. Correspondência para/Correspondence to: M.B.M. LINHARES. E-mail: <linhares@fmrp.usp.br>.

Support: Conselho Nacional de Desenvolvimento Científico e Tecnológico (Process no 301247/2010-28-8 and no 304916/2015-3) and Coordenação de Aperfeiçoamento de Pessoal de Nivel Superior (Process nº 3470/2014). 
Hospitalization is a high-risk factor for child development, especially at early ages, and represents a stressful experience for the main family caregivers, mainly affecting mother-child interactions. On one hand, hospitalization of the child provides optimal conditions for fulfilling clinical requirements in the treatment of diseases or perinatal and neonatal problems, such as prematurity, very low birth weight, and congenital problems. On the other hand, hospitalization exposes the child to a set of stressful and painful events and causes deprivation of environmental stimuli essential for development and learning. Additionally, hospitalization has a negative impact on the mother, provoking anxiety and stress (Matsuda-Castro \& Linhares, 2014; Padovani, Carvalho, Duarte, Martinez, \& Linhares, 2009) and depressive symptoms (Padovani et al., 2009).

According to the World Health Organization and the International Association for the Study of Pain (IASP), pain is a relevant worldwide problem in the healthcare field. However, despite huge investments and research efforts in relation to the issue of pain, the clinical practice is very far from the "best practices" in the hospitals. Pain is under-notified, not systematically assessed through validated instruments, poorly documented in medical charts, and, consequently, undertreated, in both developed (Stevens et al., 2011; Taylor, Boyer, \& Campbell, 2008) and developing countries (Linhares et al., 2012). The prevalence, assessment, and management of pediatric pain was examined in a Brazilian public teaching hospital, with the findings providing evidence of the high prevalence of pain in pediatric inpatients and the under-recognition of pain by health professionals (Linhares et al., 2012). In this Brazilian audit study, with 34 children/adolescents interviewed, 59\% reported pain, $68 \%$ of whom reported that they received pharmacological intervention for pain relief. Of the 82 family caregivers interviewed, $49 \%$ had observed a pain response in their child, and $74 \%$ reported that the inpatients had received pharmacological management. In the inpatients exhibited signs of pain, these being predominantly linked to acute pain detected during clinical procedures, with $68 \%$ of the patients receiving pharmacological interventions. The nurses reported that pain was managed in $78 \%$ of the inpatients through pharmacological and/or non-pharmacological interventions. In this study, the majority of the 121 inpatients were infants, especially preterm neonates undergoing intensive care treatment, who could not report their pain.

The Neonatal Intensive Care Unit (NICU) is a stressful environment, including events of different stressful levels (extremely, very, moderately, and slightly), depending on the specific treatment of the inpatients (Newnham, Inder, \& Milgrom, 2009). The clinical health status of the newborn is directly associated with gestational age and birth weight, with increased lengths of stay in NICU related to more painful procedures in the neonatal pain history (Goffaux et al., 2008; Valeri, Gaspardo, Martinez, \& Linhares, 2012; Williams, Ktattak, Garza, \& Lasky, 2009). The inpatients of the NICU are mainly preterm and very low birth weight newborns with clinical diseases associated, such as intracranial hemorrhage, bronchopulmonary dysplasia, and/or retinopathy of prematurity. Infants born prematurely are defined as those born before 37 weeks of gestational age. The estimate is that 15 million preterm infants are born per year in the world, with this accounting for more than one in 10 (World Health Organization, 2016).

Preterm infants with increased severity of illness have shown greater arousal during puncture and higher physiological reactivity after a puncture than clinically stable preterm infants (Valeri et al., 2012). Usually, preterm infants spend an average of two months in a NICU setting (Linhares, Gaspardo, Souza, Valeri, \& Martinez, 2014), characterizing a toxic stress experience during early development. Toxic stress consists of high reactivity, with frequent and ongoing arousal of the body in response to stressful events (Garner et al., 2012; Shonkoff, 2010; Shonkoff \& Levitt, 2010; Shonkoff et al., 2012). The stressful experience at early ages with no adequate protective support could have a 
negative impact on the development in the short-, medium- and long-term (Linhares, 2016) and on health in adulthood (Shonkoff, 2012).

The pain experience in the NICU constitutes an extreme toxic stress event for infants during early development. These experiences provoke biobehavioral activation of vulnerable infants, who have a poor self-regulated developmental process in this phase. In the neonatal phase, the developmental regulation process is focused on physiological regulation, with an evolution to the emotional and behavioral regulation processes coming later (Sameroff, 2009). Protective mechanisms should be employed to promote the balance of the reactivity-recovery system and, consequently, enhance the regulatory processes. Therefore, the prevention and treatment of pain in vulnerable infants during the neonatal phase needs to be implemented in hospital settings, aiming to protect the development of the infant. The interdisciplinary health professionals that take care of infants in the NICU setting should play an active co-regulation role, providing external protective support for the development of the newborns.

\section{Definition of pain}

The International Association for the Study of Pain defines pain as the following: "An unpleasant sensory and emotional experience associated with actual or potential tissue damage, or described in terms of such damage" (International Association for the Study of Pain, 1994, para.3). It is important to note that, even in vulnerable populations of infants with an inability to communicate the pain symptoms verbally, pain experiences can be detected. Consequently, they need to be protected against these stressful and painful experiences during early development. Pain is always subjective, however, their experiences can be measured by objective biobehavioral responses (such as, specific facial activity and body movements, heart rate, cortisol levels, oxygen saturation, and sleepwake states) (Stevens et al., 2007). Pain is a tissue damage experience, which is associated with actual or potential damage, causing an unpleasant and therefore emotional experience.

Recently, the definition of pain proposed by the International Association for the Study of Pain was reviewed by Williams and Craig (2016), based on the reasoning that the pain definition was partial, omitting qualities such as the cognitive and social dimensions. The authors suggested a discussion among researchers and clinicians to update the IASP's pain definition. They highlighted that there have been substantial advances in science, which are not reflected in the stated pain definition, aiming for a more balanced and comprehensive approach of pain. They recommended emphasizing behavioral responses in all pain assessments, accepting that psychological implications can be present even when there is no tissue damage.

According to the International Association for the Study of Pain (1994), pain can be classified, as the following: acute, chronic or recurrent. Acute pain presents a short duration related to tissue injury or physiological process, which stops when the painful stimulus finishes. Frequently, acute procedural pain is associated with routine intensive treatments of infants in the NICU, according to the clinical requirements, such as puncture for blood collection exam, aspiration, and injection procedures. The evolution of chronic pain, in turn, is characterized by pain symptoms persisting for at least three months, with the pain being related to a certain disease. Finally, recurrent pain develops with variations in duration, intensity, and frequency, which are separated by asymptomatic periods.

\section{Impact of pain on development}

Neonatal intensive care exposes the infants to many painful and stressful procedures, which cumulatively, could affect later neurodevelopmental outcomes. Recently, there has been an investment in studies with prospective-longitudinal designs aiming to examine the impact of the exposure to neonatal pain-related stress on the development 
of the child. A systematic review of the literature showed that acute pain-related stress events experienced in the early neonatal phase have a negative impact on the development of the child, even when controlling for the clinical severity of illness of the preterm newborn samples (Valeri, Holsti, \& Linhares, 2015). This review showed that in infants born extremely preterm greater numbers of painful procedures were associated with delayed postnatal growth, poor early neurodevelopment, high cortical activation and altered brain development. Biobehavioral pain reactivity-recovery responses in very preterm infants were associated with later negative affectivity temperament during toddlerhood. Furthermore, greater numbers of neonatal painful experiences were associated with poor cognitive and motor development outcomes at one year of age, and changes in cortical rhythmicity and cortical thickness in school-age children.

The assessment of pain should be performed to support clinical decisions regarding appropriate pain relief management and to attenuate the potential negative impact on the early and later development of the child (Hall \& Anand, 2014; Roofthooft, Simons, Anand, \& van Dijik, 2014). Pain management and comfort interventions increase the homeostasis and stability of preterm infants and help immature newborns cope with pain-related stress events in the NICU (Campbell-Yeo et al., 2012; Johnston et al., 2014).

\section{Developmental care}

Pain management protocols are directly associated with Developmental Care guidelines in the NICU setting. In the 1980s, Heidelise Als developed a program of protection for the development of preterm newborns, called the "Newborn Individualized Developmental Care and Assessment Program" (NIDCAP), which aims to positively modify the intensive care unit environment (Als, 1982; Als et al., 2004). The NIDCAP involves, among other interventions, reductions of light, noise and handling, as well as providing rest periods for the newborn, in order to reduce the high level of environmental stress. Later on, other developmental care interventions in the NICU were also systematized. The Developmental Care has been shown to have beneficial effects on the development and health of preterm infants in the neonatal period and in the first year of age (Gaspardo, Martinez, \& Linhares, 2010). The Developmental Care interventions improved outcomes in the short-term, such as the physiological, behavioral, neurological and clinical status of newborns (Als et al., 2003). Decreased pain reactivity of infants was noted during weighing (Catelin, Tordjman, Morin, Oger, \& Sizun, 2005) and diaper changing (Sizun, Ansquer, Browne, Tordjaman, \& Morin, 2002) procedures. Parents exposed to Developmental Care interventions showed a higher sense of competence to take care of the infants (Ohgi, Fukuda, Akiyama, \& Gima, 2004).

Developmental Care practices support better neurobehavioral stability in very preterm infants (Montirosso et al., 2012). Infants from NICU with infant-centered care practices, such as involvement of the parents, use of kangaroo care as a routine procedure and the presence of nursing interventions to support infant development by decreasing infant energy expenditure and promoting stability, showed greater attention and regulation, less excitability and hypotonicity, and lower levels of stress, compared to infants from low-care NICU (Montirosso et al., 2012).

Pain management constitutes part of the whole procedure of developmental care for infants hospitalized in the NICU; however, the pain issue needs further clear pharmacological and nonpharmacological guidelines for pain relief and protection of development against stressful and painful events.

\section{Non-pharmacological management of neonatal pain}

The non-pharmacological management 
of neonatal pain mainly includes prevention of pain-related stress experiences in the vulnerable population of preterm and full-term infants. During hospitalization in the NICU, preterm newborns experience an average of six painful procedures daily (Gaspardo, Chimello, Cugler, Martinez, \& Linhares, 2008), and additionally suffer other extreme or moderate stressful events, such as, intubation, eye examination, lumbar puncture, heel pricks, and nasogastric tube insertion (Gorzílio, Garrido, Gaspardo, Martinez, \& Linhares, 2015). The scientific, evidence-based, non-pharmacological management of neonatal acute pain (Cignacco et al., 2007; Fernandes, Campbel-Yeo, \& Johnston, 2011) includes the following: (i) breastfeeding or human milk (as well as the unquestionable nutritional benefits of human milk for the infants, it is a potent pain relief intervention when used with breastfeeding or via oral-gastric tube); (ii) non-nutritive sucking (32 sucking behaviors per minute have an analgesic effect; a pacifier can be used); (iii) facilitatedtucking (placing the arms and legs of the infant near the trunk to maintain a flexed in utero posture, with limbs placed in body midline); (iv) swaddling (wrapping the infants in a sheet or blanket, limbs flexed, head, shoulders and hips neutral without rotation and hands accessible for exploration); (v) skin-to-skin (positioning of clinically stable infants against the breast of the mother allows them to be warmed, facilitates breastfeeding, sensitizes them to attachment, and relieves pain during medical procedures). The skin-to-skin position with the mother for 30 minutes is more effective for the pain relief of infants than 15 or 80 minutes (Cong, Ludington-Hoe, \& Walsh, 2011; Cong et al., 2012). In addition, the findings are inconclusive regarding whether the skin-to-skin position with fathers and others caregivers is as efficient as with mothers in relation to protecting infants against pain experiences (Johnston, Campbell-Yeo, \& Filion, 2011; Johnston et al., 2012).

It is important to note that all these pain strategies stimulate the infants in relevant developmental systems, such as oral, vestibular, and motor. In addition, the breastfeeding and the skinto-skin contact comprise part of a whole process of parenting, taking care of infants, acting for pain relief, and, naturally, promoting the mother-child interactions, which are protective for the emotional development of infants (Craig et al., 2015; Phillips, 2015).

Additionally, a range of sweet solutions, such as sucrose and glucose, are used to prevent acute-procedural pain in the NICU (Matar, Arabiat, \& Foster, 2016; Mokhnach et al., 2010; Stevens, Yamada, Ohlsson, Haliburton, \& Shorkey, 2016). Studies performed at the Clinical Hospital of Ribeirão Preto, of the Medical School of Universidade de São Paulo, showed that the use of repeated doses of oral sucrose in the NICU was effective in reducing procedural pain and increasing biobehavioral regulation, independent of the neonatal clinical risk level of the preterm newborns, with no clinical side effects detected (Gaspardo, Miyase, Chimello, Martinez, \& Linhares, 2008; Linhares et al., 2014; Valeri, 2015). The administration of these solutions should follow the specific recommendation guidelines, which have established the optimum doses and concentration to be efficacious for pain relief. Currently, there is no consensus in the scientific literature regarding whether these solutions should be classified as non-pharmacological or pharmacological neonatal pain management. However, there is a consensus that the administration of these solutions should be prescribed and documented in the medical charts (Committee on Fetus and Newborn \& Section on Anesthesiology and Pain Medicine, 2016; Lefrak et al., 2006).

\section{Clinical practice implications}

Considering that pain experiences affect the development of the child, the clinical practice of the interdisciplinary health team needs to include protection mechanisms for vulnerable infants exposed to the environment of toxic stress of the NICU. In the developmental care initiative in the 
NICU (Fernandes et al., 2011; Gaspardo et al., 2010; Symington \& Pinelli, 2002), professionals need to protect the infants against discomfort, distress, and pain experiences, performing the following actions: (a) moderating the negative effects of sound and light; (b) avoiding or reducing excessive and disorganized handling the infants, aiming to promote cluster-care; (c) facilitating the sleep states and reducing the crying states, as they provoke excessive energy expenditure in preterm infants; and (d) using facilitated tucking and promoting skin-to-skin contact, to implement pain management. Thus, infants will be protected and will achieve more organized physiological, emotional and behavioral regulation in their developmental processes. When the infants have more biobehavioral stability and regulation it becomes easier for the mothers to be close to the infants during their waking states, representing a special moment for stimulating the attachment. Finally, the main component of mother-infant interactions could be stimulated by the health professionals supporting mothers to establish good strategies for touching, talking and gazing at the infants under the special and restricted conditions of the NICU environment (Craig et al., 2015; Phillips, 2015).

The inclusion of psychologists in the health professional teams is crucial, primarily, to promote the attachment in the mother-infant interactions and to support the mothers and other caregivers in coping with the stressful situation of having a newborn infant hospitalized in the NICU. It is important to note that, secure attachment is related to successful breastfeeding. The assessment of the anxiety, stress, and depressive symptoms of mothers is also essential for clinical decisions related to support for their better emotional regulation (Hynan \& Hall, 2015). The mental health of the mothers is a protective factor for the health and development of preterm infants, especially during the early ages. Furthermore, psychologists can support the development of the infants through an optimal NICU environment, reducing stressful and painful experiences or helping them to cope with these adverse stimuli when they are inevitable. Psychologists can also participate in the developmental care training of the clinical staff, especially by providing the conceptual framework of child development and psychopathology development and strategies to psychologically protect the preterm infants and their mothers or other family caregivers (fathers, grandmothers/ grandfathers, siblings).

Focusing on pain management in the $\mathrm{NICU}$, the psychologists could actively participate in the following actions: implementing nonpharmacological interventions, as well as the whole process to sensitize and train the professional teams; alerting parents to the relevance of protection of the infants against pain; and supporting the policymakers to implement assessments and pain management guidelines in the hospital, achieving an institutional pain policy system. Accordingly, a pain program called HC-Criança sem dor (Children without pain) has been implemented in a tertiary university hospital in Southwest of the state of São Paulo, Brazil (Children's Hospital of the Clinical Hospital of Ribeirão Preto Medical School - Universidade de São Paulo) by a multidisciplinary team, including psychologists. This program was based on the principles of Childkind (Schechter, Finley, Bright, Laycock, \& Forgeron, 2010) and aimed to: i) implement the assessment of pediatric pain and guidelines for pain relief management based on evidence and scientific knowledge; ii) provide continuing education for the multidisciplinary health teams; and iii) assess the hospital institution continuously regarding pain management in the different services (audits). The hospital teams are now more sensitized to pediatric pain issues, use of the written assessment form, prevention, and treatment guideline for clinical practice, with the distribution of handouts that summarize these guidelines. In the next step, training and updates regarding pain assessment and management will be implemented for professionals of the multidisciplinary teams of the Nursery, Neonatal Intensive Care Unit, and Pediatric Intensive Care Unit of the Children's Hospital. 
The great challenges are in defining the programs and actions to implement successful training in pediatric pain issues for multidisciplinary teams and convincing policymakers to adopt institutional pediatric pain models in the clinical practices within the hospital services. For both purposes, evidence-based scientific knowledge is essential to achieve a high level of pain assistance for patients and their family caregivers. Future studies and clinical actions should invest more in chronic pain issues, especially regarding the assessment of specific pain and its management in a different way to acute pain. Chronic pain involves also other psychological variables, such as depressive symptoms, and implications for quality life, that need specific psychological support.

\section{Contributors}

M.B.M. LINHARES and C.M. GASPARDO conceptualized, wrote, revised the manuscript, and approved the final version.

\section{References}

Als, H. (1982). Toward a synactive theory of development: Promise for the assessment and support of infant individuality. Infant Mental Health Journal, 3(4), 229-243. https://doi. org/10.1002/1097-0355(198224)3:4<229::AIDIMHJ2280030405>3.0.CO;2-H

Als, H., Duffy, F. H., McAnulty, G. B., Rivkin, M. J., Vajapeyam, S., Mulkern, R. V., \& Eichenwald, E. (2004). Early experience alters brain functions and structure. Pediatrics, 113(4), 846-857. https://doi.org/10.1542/ peds.113.4.846

Als, H., Gilkerson, L., Duffy, F. H., McAnulty, G. B., Buehler, D. M., Vandenberg, K, \& Jones, K. J. (2003). A threecenter, randomized, controlled trial of individualized developmental care for very low birth weight preterm infants: Medical, neurodevelopmental, parenting, and caregiving effects. Journal of Developmental and Behavioral Pediatrics, 24(6), 399-408.

Campbell-Yeo, M. L., Johnston, C. C., Joseph, K. S., Feeley, N., Chambers, C. T., \& Barrington, K. J. (2012). Cobedding and recovery time after heel lance in preterm twins: Results of a randomized trial.
Pediatrics, 130(3), 500-506. https://doi.org/10.1542/ peds.2012-0010

Catelin, C., Tordjman, S., Morin, V., Oger, E., \& Sizun, J. (2005). Clinical, physiologic, and biologic impact of environmental and behavioral interventions in neonates during a routine nursing procedure. Journal of Pain, 6(12), 791-797. https://doi.org/10.1016/j. jpain.2005.07.010

Cignacco, E., Hamers, J. P., Stoffel, L., van Linger, R. A., Gessler, P., McDougall, J., \& Nelle, M. (2007). The efficacy of non-pharmacological interventions in the management of procedural pain in preterm and term neonates. A systematic literature review. European Journal of Pain, 11(2), 139-152. https://doi. org/10.1016/j.ejpain.2006.02.010

Committee on Fetus and Newborn \& Section on Anesthesiology and Pain Medicine. (2016). Prevention and management of procedural pain in the neonate: An update. Pediatrics, 137(2), e20154271. https://doi. org/10.1542/peds.2015-4271

Cong, X., Cusson, R. M., Walsh, S., Hussain, N., Ludington-Hoe, S. M., \& Zhang, D. (2012). Effects of skin-to-skin contact on autonomic pain responses in preterm infants. The Journal of Pain, 13(7), 636-645. https://doi.org/10.1016/j.jpain.2012.02.008

Cong, X., Ludington-Hoe, S. M., \& Walsh, S. (2011). Randomized crossover trial of Kangaroo Care to reduce biobehavioral pain responses in preterm infants: A pilot study. Biological Research for Nursing, 13(2), 204-216. https://doi.org/10.1177/1099800410385839

Craig, J. W., Glick, C., Phillips, R., Hall, J. S., Smith, J., \& Browne, J. (2015). Recommendations for involving the family in developmental care of the NICU baby. Journal of Perinatology, 35, 55-58. https://doi.org/10.1038/ jp.2015.142

Fernandes, A., Campbell-Yeo, M., \& Johnston, C. (2011). Procedural pain management for neonates using nonpharmacological strategies. Advances in Neonatal Care, 11(4), 235-241. https://doi.org/10.1097/ ANC.0b013e318225a2c2

Gaspardo, C. M., Chimello, J. T., Cugler, T. S., Martinez, F. E., \& Linhares, M. B. M. (2008). Pain and tactile stimuli during arterial puncture in preterm neonates. Pain, 140(1), 58-64. https://doi.org/10.1016/j. pain.2008.07.004

Gaspardo, C. M., Martinez, F. E., \& Linhares, M. B. M. (2010). Developmental care: Protection approach for early development of preterm infants. Revista Paulista de Pediatria, 28(1), 77-85. https://doi.org/10.1590/ S0103-05822010000100013

Gaspardo, C. M., Miyase, C. I., Chimello, J. T., Martinez, F. E., \& Linhares, M. B. M. (2008). Is pain relief equally efficacious and free of side effects with repeated doses 
of oral sucrose in preterm neonates? Pain, 137(1), 1625. https://doi.org/10.1016/j.pain.2007.07.032

Garner, A. S., Shonkoff, J. P., Siegel, B. S., Dobbins, M. I., Earls, M. F., McGuinn, L., ... Wood, D.L. (2012). Early childhood adversity, toxic stress, and the role of the pediatrician: Translating science into lifelong health. Pediatrics, 129(1), 224-231. https://doi.org/10.1542/ peds.2011-2662

Goffaux, P., Lafrenaye, S., Morin, M., Patural, H., Demers, G., \& Marchand, S. (2008). Preterm births: Can neonatal pain alter the development of endogenous gating systems? European Journal of Pain, 12(7), 945-951. https://doi.org/10.1016/j.ejpain.2008.01.003

Gorzílio, D. M., Garrido, E., Gaspardo, C. M., Martinez, F. E., \& Linhares, M. B. M. (2015). Neurobehavioral development prior to term-age of preterm infants and acute stressful events during neonatal hospitalization. Early Human Development, 91(12), 769-775. https:// doi.org/10.1016/j.earlhumdev.2015.09.003

Hall, R. W., \& Anand, J. K. (2014). Pain management in newborns. Clinics in Perinatology, 41(4), 895-924. https://doi.org/10.1016/j.clp.2014.08.010

Hynan, M. T., \& Hall, S. L. (2015). Psychosocial program standards for NICU parents. Journal of Perinatology, 35(Suppl.1), 51-54. https://doi.org/10.1038/jp.2015.141

International Association for the Study of Pain. (1994). IASP taxonomy. Retrieved November 30, 2016, from http:// www.iasp-pain.org/Taxonomy?navltemNumber=576

Johnston, C. C., Campbell-Yeo, M., Fernandes, A., Inglis, D., Streiner, D., \& Zee, R. (2014). Skin-to-skin care for procedural pain in neonates. Cochrane Database System Review, 1:CD008435. https://doi. org/10.1002/14651858.CD008435.pub2

Johnston, C. C., Campbell-Yeo, M., \& Filion, F. (2011). Paternal vs maternal Kangaroo Care for procedure pain in preterm neonates: A randomized crossover trial. Archives of Pediatric and Adolescent Medicine Journal, 165(9), 792-796. https://doi.org/10.1001/ archpediatrics.2011.130

Johnston, C., Byron, J., Filion, F., Campbell-Yeo, M., Gibbins, S., \& Ng, E. (2012). Alternative female Kangaroo Care for procedural pain in preterm neonates: A pilot study. Acta Paediatrica, 101(11), 1147-1150. https://doi. org/10.1111/j.1651-2227.2012.02813.x

Lefrak, L., Burch, K., Caravantes, R., Knoerlein, K., DeNolf, N., Duncan, J., ... Toczylowski, K. (2006). Sucrose analgesia: Identifying potentially better practices. Pediatrics, 118(Suppl.2), 197-202. https://doi. org/10.1542/peds.2006-0913R

Linhares, M. B. M. (2016). Early childhood stress: Impacts on health and protective mechanisms. Estudos de Psicologia (Campinas), 33(4), 587-599. https://doi. org/10.1590/1982-02752016000400003
Linhares, M. B. M., Gaspardo, C. M., Souza, L. O., Valeri, B. O., \& Martinez. (2014). Examining the side effects of sucrose for pain relief in preterm infants: A case-control study. Brazilian Journal of Medical and Biological Research, 47(6), 527-532. https://doi. org/10.1590/1414-431X20143659

Linhares, M. B. M., Doca, F. N. P., Martinez, F. E., Carlotti, A. P. P., Cassiano, R. G. M., Pfeifer, L. I., ... Finley, G. A. (2012). Pediatric pain: Prevalence, assessment, and management in a teaching hospital. Brazilian Journal of Medical and Biological Research, 45(12), 1287-1294. https://doi.org/10.1590/S0100-879X2012007500147

Matar, E. M., Arabiat, D. H., \& Foster, M. J. (2016). Oral glucose efficacy on neonate's pain responses at the NICU: A quasi experimental trial of two clinical procedures. Applied Nursing Research, 32, 36-40. https://doi.org/10.1016/j.apnr.2016.04.002

Matsuda-Castro, A. C., \& Linhares, M. B. M. (2014). Pain and distress in inpatient children according to child and mother perception. Paidéia, 24(2), 351-359. https:// doi.org/10.1590/1982-43272459201409

Mokhnach, L., Anderson, M., Glorioso, R., Loeffler, K., Shinabarger, K., Thorngate, L., ... Zbirun I. (2010). NICU procedures are getting sweeter: Development of a sucrose protocol for neonatal procedural pain. Neonatal Network, 29(5), 271-279. https://doi. org/10.1891/0730-0832.29.5.271

Newnham, C. A., Inder, T. E., \& Milgrom, J. (2009). Measuring preterm cumulative stressors within the NICU: The Neonatal Infant Stressor Scale. Early Human Development, 85(9), 549-555. https://doi. org/10.1016/j.earlhumdev.2009.05.002

Montirosso, R., Del Prete, A., Bellù, R., Tronick, E., Borgatti, R., \& Neonatal Adequate Care for Quality of Life (NEOACQUA) Study Group. (2012). Level of NICU quality of developmental care and neurobehavioral performance in very preterm infants. Pediatrics, 129(5), 1129-1137. https://doi.org/10.1542/peds.2011-0813

Ohgi, S., Fukuda, M., Akiyama, T., \& Gima, H. (2004). Effect of an early intervention programme on low birthweight infants with cerebral injuries. Journal of Paediatric Child Health, 40(12), 689-695. https://doi. org/10.1111/j.1440-1754.2004.00512.x

Padovani, F. H. P., Carvalho, A. E. V., Duarte, G., Martinez, M. B. M., \& Linhares, M. B. M. (2009). Anxiety, dysphoria and depression symptoms in mothers of preterm infants. Psychological Reports, 104(2), 667679. https://doi.org/10.2466/pr0.104.2.667-679

Phillips, R. M. (2015). Seven core measures of neuroprotective family-centered developmental care: Creating an infrastructure for implementation. Newborn \& Infant Nursing Reviews, 15(3), 87-90. https://doi.org/10.1053/j.nainr.2015.06.004 
Roofthooft, D., Simons, S., Anand, K., \& van Dijik, M. (2014). Eight years later, are we still hurting newborn infants? Neonatology, 105(3), 218-226. https://doi. org/10.1159/000357207

Sameroff, A. J. (2009). Conceptual issues in studying the development of self-regulation. In S. L. Olson \& A. J. Sameroff (Eds.), Biopsychosocial regulatory processes in the development of childhood behavioral problems. New York: Cambridge University Press.

Schechter, N. L., Finley, G. A., Bright, N. S., Laycock, M., \& Forgeron P. (2010). ChildKind: A global initiative to reduce pain in children. Pediatric Pain Letter, 12(3), 26-30.

Shonkoff, J. P. (2010). Building a new biodevelopmental framework to guide the future of early childhood policy. Child Development, 81(1), 357-367. https://doi. org/10.1111/j.1467-8624.2009.01399.x

Shonkoff, J. P. (2012). Leveraging the biology of adversity to address the roots of disparities in health and development. Proceedings of the National Academy of Science of the United States of America, 109(2), 1730217307. https://doi.org/10.1073/pnas.1121259109

Shonkoff, J. P., Garner, A. S., Siegel, B. S., Dobbins, M. I., Earls, M. F., McGuinn, L., ... Wood, D. L. (2012). The lifelong effects of early childhood adversity and toxic stress. Pediatrics, 129(1), 232-246. https://doi. org/10.1542/peds.2011-2663

Shonkoff, J. P., \& Levitt, P. (2010). Neuroscience and the future of early childhood policy: Moving from why to what and how. Neuron, 67(5), 689-691. https://doi. org/10.1016/j.neuron.2010.02.032

Sizun, J., Ansquer, H., Browne, J., Tordjaman, S., \& Morin, J. F. (2002). Developmental care decreases physiologic and behavioral pain expression in preterm neonates. Journal of Pain, 3(6), 446-450.

Stevens, B. J., Abbott, L. K., Yamada, J., Harrison, D., Stinson J., Taddio, A., ... CIHR Team in Children's Pain. (2011). Epidemiology and management of painful procedures in children in Canadian hospitals. Canadian Medical Association Journal, 183(7), 403-410. https:// doi.org/10.1503/cmaj. 101341

Stevens, B. J., McGrath, P., Gibbins, S., Beyene, J., Breau, L., Camfield, C., ... Yamada, J. (2007). Determining behavioural and physiological responses to pain in infants at risk for neurological impairment. Pain, 127(1-
2), 94-102. https://doi.org/10.1016/j.pain.2006.08.012

Stevens, B., Yamada, J., Ohlsson, A., Haliburton, S., \& Shorkey, A. (2016). Sucrose for analgesia in newborn infants undergoing painful procedures. Cochrane Database System Review, 1:CD001069. https://doi. org/10.1002/14651858.CD001069.pub5

Symington, A., \& Pinelli, J. M. (2002). Distilling the evidence on developmental care: A systematic review. Advances in Neonatal Care, 2(4), 198-221.

Taylor, E. M., Boyer, K., \& Campbell, F. A. (2008). Pain in hospitalized children: A prospective cross-sectional survey of pain prevalence, intensity, assessment and management in a Canadian pediatric teaching hospital. Pain Research and Management, 13(1), 25-32.

Valeri, B. (2015). Reatividade à dor em neonatos pré-termo sob intervenção de sacarose, em grupos diferenciados pelo risco clínico neonatal (Tese de doutorado nãopublicada). Universidade de São Paulo.

Valeri, B. O., Gaspardo, C. M., Martinez, F. E., \& Linhares, M. B. M. (2012). Does the neonatal clinical risk for illness severity influence pain reactivity and recovery in preterm infants? European Journal of Pain, 16(5), 727-736. https://doi.org/10.1002/j.15322149.2011.00037.x

Valeri, B. O., Holsti, L., \& Linhares, M. B. (2015). Neonatal pain and developmental outcomes in children born preterm. The Clinical Journal of Pain, 31(4), 355-362. https://doi.org/10.1097/AJP.0000000000000114

Williams, A. C., \& Craig. K. D. (2016). Updating the definition of pain. Pain, 157(11) 2420-2423. https:// doi.org/10.1097/j.pain.000000000000613

Williams, A. L., Khattak, A. Z., Garza, C. N., \& Lasky R. E. (2009). The behavioral pains response to heel stick in preterm neonates studied longitudinally: Description, development, determinants, and components. Early Human Development, 85(6), 369-374. https://doi. org/10.1016/j.earlhumdev.2009.01.001

World Health Organization. (2016). Preterm birth: Fact sheet. Retrieved November 2, 2016, from http://www. who.int/mediacentre/factsheets/fs363/en/

Received: March 6, 2017

Approved: March 28, 2017 
